\title{
Kajian Pengelolaan Limbah Elektronik di Unit Pendidikan ITS
}

\author{
Ignatius Chandra Setyanto dan Yulinah Trihadiningrum \\ Departemen Teknik Lingkungan, Fakultas Teknik Sipil dan Perencanaan, Institut Teknologi Sepuluh Nopember \\ (ITS) \\ e-mail: yulinah_t@enviro.its.ac.id
}

\begin{abstract}
Abstrak-Limbah elektronik merupakan limbah bahan berbahaya dan beracun (B3) yang saat ini telah menjadi perhatian utama dunia. Limbah elektronik mengandung substansi berbahaya seperti timbal, merkuri, kadmium dan bahan berbahaya lainnya. Institut Teknologi Sepuluh Nopember (ITS) menggunakan berbagai macam barang elektronik untuk mendukung sarana dan prasarana dalam proses belajar mengajar di lingkungan kampus. Barang elektronik tersebut dalam kurun waktu tertentu akan menjadi limbah elektronik dan dapat mencemari lingkungan apabila tidak dikelola dengan tepat. Tujuan penelitian ini adalah menganalisis dan melakukan penilaian kesesuaian kondisi pengelolaan limbah elektronik di unit pendidikan ITS terhadap peraturan tentang pengelolaan limbah B3 yang berlaku di Indonesia. Pada penelitian ini terdapat 2 aspek yang ditinjau, yaitu aspek teknis serta aspek kelembagaan. Hasil penelitian data bahwa unit pendidikan ITS yang diteliti saat ini menyimpan berbagai jenis limbah elektronik, yaitu perangkat IT seperti: CPU; keyboard; mouse, laptop, printer; faksimile; dan mesin fotokopi, kemudian alat elektronik rumah tangga berukuran besar seperti: lemari pendingin; kipas angin dan $\mathrm{AC}$, alat elektronik untuk pencahayaan serta alat elektronik untuk laboratorium. Jumlah limbah elektronik yang disimpan oleh unit pendidikan ITS yang diteliti mencapai 1289 unit, dengan total berat $16180 \mathrm{~kg}$ dan total volume $100.5 \mathrm{~m}^{3}$. Limbah elektronik tersebut telah dikelola namun masih terdapat kekurangan dalam aspek-aspek tertentu. Kekurangan tersebut disebabkan oleh beberapa faktor, diantaranya: keterbatasan kapasitas ruang penyimpanan limbah elektronik, kurangnya pengetahuan SDM pada masing-masing departemen tentang pengelolaan limbah B3 khususnya limbah elektronik, belum adanya kebijakan dari pimpinan ITS tentang pengelolaan limbah elektronik, dan tidak jelasnya mekanisme pemutihan barang milik negara.
\end{abstract}

Kata Kunci-B3, ITS, Limbah Elektronik, Pengelolaan, Unit Pendidikan.

\section{PENDAHULUAN}

I NOVASI barang elektronik terus bermunculan baik dari aspek desain, fungsi, mobilitas, maupun aspek-aspek lainnya dalam 20 tahun terakhir, sehingga menyebabkan barang elektronik menjadi cepat usang [1]. Peningkatan laju timbulan limbah elektronik mencapai 5\% tiap tahunnya secara global, dan volume limbah elektronik meningkat hingga 500\% untuk 1 dekade berikutnya pada beberapa negara [2]. Masa pakai dari barang-barang elektronik mengalami pengurangan akibat dari kemajuan teknologi, strategi pemasaran, serta penyesuaian dengan permasalahan yang sedang dihadapi masyarakat saat ini. Pengurangan masa pakai dari barang elektronik berbanding lurus dengan peningkatan laju timbulan limbah elektronik tiap waktu [1].
Peralatan elektronik merupakan peralatan yang membutuhkan arus listrik atau medan elektromagnet untuk bekerja secara normal dan peralatan untuk pembangkit, transfer dan pengukuran arus listrik pada muatan tertentu. Peralatan elektronik didesain untuk digunakan dengan tegangan tidak melebihi 1000 volt untuk arus bolak-balik dan 1500 volt untuk arus searah. Limbah elektronik merupakan peralatan elektrik dan elektronik yang sudah dibuang, termasuk semua komponen, bagian rakitan dan bahan habis yang adalah bagian dari produk [3].

Limbah elektronik atau electronic waste (e-waste) dikategorikan sebagai limbah Bahan Beracun dan Berbahaya (B3) karena mengandung substansi yang berbahaya seperti timbal, merkuri, kadmium dan substansi berbahaya lainnya [4]. Komponen-komponen tersebut merupakan bahan toksik yang diketahui sangat persistent dan dapat terakumulasi. Sehingga bila limbah elektronik tidak dikelola dengan baik, maka bahan-bahan kimia tersebut dapat terlepas dan mencemari lingkungan. Laju timbulan limbah elektronik yang tinggi menyebabkan proses akumulasi pencemaran menjadi cepat, dan membawa dampak yang sangat berbahaya bagi kesehatan dan lingkungan [5].

Pengelolaan limbah elektronik belum menjadi perhatian utama di beberapa negara berkembang, termasuk di Indonesia. Regulasi terkait pengelolaan limbah elektronik di Indonesia diatur dalam Peraturan Pemerintah Republik Indonesia Nomor 101 Tahun 2014 tentang Pengelolaan Limbah Bahan Berbahaya dan Beracun [6]. Pengelolaan terkait limbah elektronik di sektor formal ataupun informal belum dibahas secara spesifik dalam peraturan tersebut. Institusi pendidikan tinggi sebagai sektor pendidikan formal membutuhkan regulasi khusus untuk mengelola limbah elektronik yang dihasilkan.

Pada negara maju, Massachusetts Institute of Technology (MIT) merupakan salah satu contoh institusi pendidikan tinggi yang telah melakukan pengelolaan limbah elektronik skala kampus dan memiliki regulasi khusus untuk mengelola limbah elektronik. Pengelolaan limbah elektronik MIT diatur dalam dokumen "Universal and Electronic Waste Management for the MIT Community". Dalam dokumen tersebut terdapat penggolongan jenis limbah elektronik, tahapan penanganan serta penyimpanan limbah elektronik [7]. Pada negara berkembang, Jomo Kenyatta University (JKUAT) adalah salah satu contoh universitas yang telah melakukan pengelolaan limbah elektronik. JKUAT telah menyusun kebijakan terkait manajemen limbah elektronik yang memuat tentang perlunya kerangka hukum, peningkatan kapasitas sumber daya manusia, peningkatan kesadaran masyarakat, pengelolaan limbah yang 
ramah lingkungan, serta upaya untuk mobilisasi sumber daya [8].

Berdasarkan latar belakang diatas, maka dilakukan kajian pengelolaan limbah elektronik di unit pendidikan ITS untuk menganalisis kondisi pengelolaan limbah elektronik pada tiap unit pendidikan. Kajian dilakukan pada aspek teknis dan kelembagaan.

\section{METODE PENELITIAN}

\section{A. Tahap Survei dan Persiapan}

Beberapa unit pendidikan (departemen) dipilih untuk menjadi sampel/objek penelitian. Metode yang digunakan adalah metode cluster. Cluster didasarkan pada jumlah mahasiswa S1 di masing-masing departemen yang terdata oleh ITS pada tahun 2016 seperti ditunjukan pada Tabel 1.

Tabel 1.

Jumlah Mahasiswa Tiap Departemen di ITS Tahun 2016

\begin{tabular}{ccc}
\hline \hline \multicolumn{1}{c}{ Jumlah Mahasiswa (orang) } & $>800$ \\
\hline Teknik Geomatika & $400-800$ & Teknik Sipil \\
Teknik Geofisika & Teknik Lingkungan & Desain Produk Industri \\
dan Desain Interior & Teknik Elektro \\
Manajemen Bisnis & Perencanaan Wilayah Kota & Teknik Mesin \\
Teknik Multimedia & Arsitektur & - \\
dan Jaringan & Teknik Kimia & - \\
Teknik Biomedik & Teknik Industri & - \\
Sistem Transportasi & Teknik Fisika & - \\
Laut & Teknik Material dan Metalurgi & - \\
Biologi & Teknik Kelautan & - \\
- & Teknik Perkapalan & - \\
- & Sistem Perkapalan & - \\
- & Statistika & - \\
- & Fisika & - \\
- & Kimia & - \\
- & Matematika & - \\
- & Teknik Informatika & - \\
- & Sistem Informasi & - \\
- & &
\end{tabular}

Perhitungan jumlah yang dibutuhkan adalah sebagai berikut:

- Jumlah populasi $(\mathrm{N}) \quad=28$

- Penyimpangan (d) $\quad=0.1$ (ditentukan)

- Standar deviasi $(\mathrm{z}) \quad=1.282$

- Derajat kepercayaan (q) $=95 \%$ (ditentukan)

- Jumlah sampel (n)

$\mathrm{d} \quad=z x \sqrt{\frac{p x q}{n}} x \sqrt{\frac{N-n}{N-1}}$

$0,1=1.282 \times \sqrt{\frac{0,05 \times 0,95}{n}} \times \sqrt{\frac{28-n}{28-1}}$

$\mathrm{n} \quad=7$

Hasil perhitungan menunjukan bahwa dibutuhkan 7 departemen sebagai objek penelitian. Kemudian ditentukan sampel dari masing-masing cluster yang telah disusun.

- Departemen dengan mahasiswa $<400$ orang

$\mathrm{n}=\frac{7}{27} \times 7=2$ departemen

- Departemen dengan mahasiswa 400-800 orang

$\mathrm{n}=\frac{17}{27} \times 7=4$ departemen

- Departemen dengan mahasiswa $>800$ orang

$\mathrm{n}=\frac{3}{27} \times 7=1$ departemen
Departemen dari masing-masing dipilih secara acak dan didapatkan departemen yang menjadi objek penelitian adalah departemen: Teknik Lingkungan, Teknik Arsitektur, Teknik Geofisika, Biologi, Sistem Informasi, Teknik Kelautan, dan Teknik Elektro.

\section{B. Tahap Pengambilan Data}

Data limbah elektronik yang dibutuhkan adalah jenis dan kuantitas limbah elektronik. Data kuantitas terdiri atas jumlah (unit), berat $(\mathrm{kg})$, dan volume $\left(\mathrm{m}^{3}\right)$ limbah elektronik. Kemudian dilakukan observasi untuk menilai kondisi pengelolaan limbah elektronik departemen yang diteliti. Penilaian menggunakan PP RI No. 101 Tahun 2014 sebagai dasar perbandingannya.

\section{Tahap Analisis Data}

Data yang didapatkan kemudian dianalisis untuk mengetahui faktor-faktor yang mempengaruhi pengelolaan limbah elektronik di unit pendidikan ITS. Analisis dilakukan dengan meninjau aspek yang menjadi permasalahan utama dalam pelaksanaan pengelolaan limbah elektronik.

\section{HASIL DAN PEMBAHASAN}

\section{A. Data Jenis dan Kuantitas Limbah Elektronik}

Pengambilan data menggunakan data primer. Namun pada beberapa departemen limbah elektronik disimpan pada ruang penyimpanan yang bercampur dengan jenis limbah lainnya. Ruang penyimpanan sangat penuh sehingga pengambilan data limbah elektronik menjadi sulit dan tidak dapat menjangkau limbah elektronik yang mungkin berada di sudut ruang penyimpanan. Hasil pendataan jenis dan kuantitas limbah elektronik pada masing-masing departemen ditunjukkan pada Tabel 2 hingga Tabel 8.

Tabel 2.

Limbah Elektronik Departemen Teknik Lingkungan ITS

\begin{tabular}{clrrrrr}
\hline \hline $\begin{array}{c}\text { N } \\
\text { o. }\end{array}$ & $\begin{array}{c}\text { Limbah } \\
\text { Elektronik }\end{array}$ & \multicolumn{1}{c}{$\begin{array}{l}\text { Juml } \\
\text { ah }\end{array}$} & \multicolumn{1}{c}{$\begin{array}{c}\text { Berat } \\
(\mathrm{kg})\end{array}$} & $\begin{array}{c}\% \\
\text { berat }\end{array}$ & $\begin{array}{c}\text { Volume } \\
\left.\mathrm{m}^{3}\right)\end{array}$ & $\begin{array}{c}\% \\
\text { volume }\end{array}$ \\
\hline 1 & CPU & 17 & 116 & 29 & 552.6 & 25 \\
2 & Monitor $*$ & 15 & 158 & 40 & 858.6 & 39 \\
3 & Keyboard & 19 & 11 & 3 & 38.5 & 2 \\
4 & Printer & 10 & 47 & 12 & 234.2 & 11 \\
& Mesin & & & & & \\
5 Fotokopi & 1 & 38 & 10 & 110.8 & 5 \\
6 & Kipas Angin & 1 & 3 & 1 & 45 & 2 \\
7 & Lemari Es & 1 & 15 & 4 & 323.0 & 15 \\
8 & Lain-lain & 9 & 8 & 1.9 & 18.4 & 0.8 \\
\hline & Jumlah & 82 & 396.5 & 100 & 2181 & 100 \\
\hline \hline
\end{tabular}

Keterangan: *limbah elektronik dengan persentase berat dan volume terbesar limbah lain-lain berupa limbah stavolt, telepon, speaker, lampu unit, modem, portswitch, USB Portabel Diskette, router, mouse

Tabel 3.

Limbah Elektronik Departemen Sistem Informasi ITS

\begin{tabular}{clrrrrr}
\hline \hline $\begin{array}{c}\text { N } \\
\text { o. }\end{array}$ & $\begin{array}{l}\text { Limbah } \\
\text { Elektronik }\end{array}$ & $\begin{array}{c}\text { Ju } \\
\text { mlah }\end{array}$ & $\begin{array}{c}\text { Berat } \\
(\mathrm{kg})\end{array}$ & $\begin{array}{c}\% \\
\text { berat }\end{array}$ & $\begin{array}{c}\text { Volume } \\
\left(10^{-3} \mathrm{~m}^{3}\right)\end{array}$ & $\begin{array}{c}\% \\
\text { volume }\end{array}$ \\
\hline 1 & CPU & 48 & 271 & 24 & 1812 & 29 \\
2 & Monitor & 29 & 216.5 & 19 & 1092 & 18 \\
3 & Keyboard & 27 & 17.1 & 2 & 45 & 0.7 \\
4 & Printer & 5 & 12.6 & 1 & 66 & 1.1 \\
5 & Faksimile & 3 & 19 & 2 & 54 & 0.9 \\
6 & AC* & 19 & 570 & 51 & 3067 & 50 \\
& Lain-lain & 12 & 12 & 1.1 & 23 & 0.4 \\
\hline & & 14 & & & & \\
& Jumlah & 3 & 1118 & 100 & 6159 & 100 \\
\hline \hline
\end{tabular}


keterangan: *limbah elektronik dengan persentase berat dan volume terbesar limbah lain-lain berupa limbah power supply, stand lamp, portswitch, headphone.

Tabel 4.

Limbah Elektronik Departemen Teknik Geofisika ITS

\begin{tabular}{|c|c|c|c|c|c|c|}
\hline $\begin{array}{l}\mathrm{N} \\
\text { o. }\end{array}$ & $\begin{array}{c}\text { Limbah } \\
\text { Elektroni } \\
\mathrm{k}\end{array}$ & $\begin{array}{l}\text { Juml } \\
\text { ah }\end{array}$ & $\begin{array}{l}\text { Berat } \\
(\mathrm{kg})\end{array}$ & $\begin{array}{c}\% \\
\text { berat }\end{array}$ & $\begin{array}{l}\text { Volume } \\
\left.\mathrm{m}^{3}\right)\end{array}$ & $\begin{array}{c}\% \\
\text { volume }\end{array}$ \\
\hline 1 & $\begin{array}{l}\mathrm{AC}^{*} \\
\text { Kipas }\end{array}$ & 5 & 130 & 90 & 796 & 90 \\
\hline & ngin & 2 & 15.2 & 10 & 90 & 10 \\
\hline & Jumlah & 7 & 145.2 & 100 & 886 & 100 \\
\hline
\end{tabular}

Keterangan: *limbah elektronik dengan persentase berat dan volume terbesar

Tabel 5.

Limbah Elektronik Departemen Biologi ITS

\begin{tabular}{|c|c|c|c|c|c|c|}
\hline $\begin{array}{l}\mathrm{N} \\
\text { o. }\end{array}$ & $\begin{array}{c}\text { Limbah } \\
\text { Elektroni } \\
\mathrm{k}\end{array}$ & $\begin{array}{c}\text { Jumla } \\
\mathrm{h}\end{array}$ & $\begin{array}{l}\text { Berat } \\
(\mathrm{kg})\end{array}$ & $\begin{array}{c}\% \\
\text { berat }\end{array}$ & $\begin{array}{l}\text { Volume }\left(10^{-3}\right. \\
\left.\mathrm{m}^{3}\right)\end{array}$ & $\begin{array}{c}\% \\
\text { volume }\end{array}$ \\
\hline 1 & $\mathrm{CPU}$ & 4 & 22 & 5 & 133 & 6 \\
\hline 2 & Monitor & 7 & 84 & 20 & 324 & 15 \\
\hline 3 & Printer & 1 & 3 & 0.7 & 11 & 0.5 \\
\hline 4 & $\mathrm{AC}^{*}$ & 10 & 283 & 67 & 1195 & 57 \\
\hline 5 & $\begin{array}{l}\text { Lemari es } \\
\text { Lampu }\end{array}$ & 1 & 30 & 7 & 437 & 21 \\
\hline \multicolumn{2}{|c|}{$6 \mathrm{TL}$} & 1 & 0.2 & 0.05 & 0.85 & 0.04 \\
\hline & Jumlah & 24 & 422.2 & 100 & 2100 & 100 \\
\hline
\end{tabular}

Keterangan: *limbah elektronik dengan persentase berat dan volume terbesar

Tabel 6.

Limbah Elektronik Departemen Arsitektur ITS

\begin{tabular}{clrrrrr}
\hline \hline $\begin{array}{c}\mathrm{N} \\
\text { o. }\end{array}$ & $\begin{array}{c}\text { Limbah } \\
\text { Elektronik }\end{array}$ & \multicolumn{1}{c}{$\begin{array}{c}\text { Juml } \\
\text { ah }\end{array}$} & $\begin{array}{c}\text { Berat } \\
(\mathrm{kg})\end{array}$ & $\begin{array}{c}\text { \% } \\
\text { berat }\end{array}$ & $\begin{array}{c}\text { Volume } \\
\left(10^{-3} \mathrm{~m}^{3}\right)\end{array}$ & $\begin{array}{c}\% \\
\text { volume }\end{array}$ \\
\hline 1 & CPU * & 110 & 770 & 40 & 3696 & 47 \\
2 & Monitor & 30 & 360 & 19 & 1332 & 17 \\
3 & Keyboard & 27 & 32.4 & 1.7 & 149 & 1.9 \\
4 & Printer & 13 & 125 & 6 & 445 & 6 \\
5 & AC & 8 & 200 & 10 & 880 & 11 \\
6 & Projector & 3 & 30 & 1.6 & 196 & 2.5 \\
& Overhead & & & & & \\
7 & Projector & 6 & 60 & 3 & 176 & 2.2 \\
8 & Mesin Fotokopi & 1 & 200 & 10 & 25 & 0.3 \\
9 & Lemari es & 2 & 82 & 4 & 787 & 10 \\
1 & & & & & & \\
0 & Lampu TL & 60 & 12 & 0.6 & 51 & 0.6 \\
& Lain-lain & 11 & 55 & 2.9 & 153 & 1.9 \\
\hline & Jumlah & 271 & 1926.4 & 100 & 7888 & 100 \\
\hline \hline
\end{tabular}

Keterangan: *limbah elektronik dengan persentase berat dan volume terbesar limbah lain-lain berupa limbah mesin ketik, stavolt, dispenser

Tabel 7.

Limbah Elektronik Departemen Teknik Elektro ITS

\begin{tabular}{|c|c|c|c|c|c|c|}
\hline $\begin{array}{l}\mathrm{N} \\
\mathrm{o}\end{array}$ & $\begin{array}{c}\text { Limbah } \\
\text { Elektronik }\end{array}$ & $\begin{array}{c}\text { Jumla } \\
\mathrm{h}\end{array}$ & $\begin{array}{c}\text { Berat } \\
(\mathrm{kg})\end{array}$ & $\begin{array}{c}\% \\
\text { berat }\end{array}$ & $\begin{array}{c}\text { Volume } \\
\left(10^{-3}\right. \\
\mathrm{m} 3) \\
\end{array}$ & $\begin{array}{c}\% \\
\text { volume }\end{array}$ \\
\hline 1 & CPU & 191 & 955 & 9 & 9550 & 13 \\
\hline 2 & Monitor & 9 & 117 & 1 & 147 & 0.2 \\
\hline 3 & Keyboard & 17 & 17 & 0.2 & 28 & 0.04 \\
\hline 4 & Printer & 57 & 228 & 2 & 1226 & \\
\hline 5 & Scanner & 6 & 12 & 0.1 & 50 & 0.1 \\
\hline 6 & Laptop & 19 & 38 & 0.4 & 71 & 0.1 \\
\hline 7 & $\mathrm{AC}^{*}$ & 96 & 3880 & 37 & 14581 & 20 \\
\hline 8 & Faksimile & 2 & 11 & 0.1 & 35 & 0.05 \\
\hline 9 & Televisi & 5 & 75 & 0.7 & 80 & 0.1 \\
\hline 1 & & & & & & \\
\hline 0 & Dispenser & 1 & 5 & 0.05 & 123 & 0.2 \\
\hline 1 & Pesawat Telepon & 31 & 12.4 & 0.1 & 74 & 0.1 \\
\hline 2 & Mesin Jilid & 2 & 100 & 1 & 352 & 0.5 \\
\hline 3 & Oscilloscope & 2 & 20 & 0.2 & 49 & 0 \\
\hline 1 & Wheel & 8 & 1600 & 15 & 34272 & 4 \\
\hline
\end{tabular}

\begin{tabular}{|c|c|c|c|c|c|c|}
\hline $\begin{array}{l}\mathrm{N} \\
\mathrm{o} .\end{array}$ & $\begin{array}{l}\text { Limbah } \\
\text { Elektronik }\end{array}$ & $\begin{array}{c}\text { Jumla } \\
\mathrm{h}\end{array}$ & $\begin{array}{c}\text { Berat } \\
(\mathrm{kg})\end{array}$ & $\begin{array}{c}\% \\
\text { berat }\end{array}$ & $\begin{array}{l}\text { Volume } \\
\left(10^{-3}\right. \\
\text { m3) }\end{array}$ & $\begin{array}{c}\% \\
\text { volume }\end{array}$ \\
\hline \multicolumn{7}{|c|}{4 Balancer** } \\
\hline \multicolumn{7}{|l|}{1} \\
\hline 5 & Video Monitor & 10 & 200 & 2 & 3647 & \\
\hline 1 & Universal Test & 3 & 540 & 5 & 2849 & \\
\hline 6 & Machine & 3 & 340 & 5 & 1 & \\
\hline 7 & Loudspeaker & 9 & 153 & 1 & 695 & 1.0 \\
\hline \multicolumn{7}{|c|}{ secosp } \\
\hline \multirow{2}{*}{\multicolumn{7}{|c|}{ Centrifuge }} \\
\hline & & & & & & \\
\hline \multirow[t]{2}{*}{9} & Voltmeter & 33 & 16 & 0.2 & 16.5 & 0.02 \\
\hline & Lain-lain & 54 & 321 & 3 & 691 & 1.2 \\
\hline \multicolumn{7}{|c|}{10500.} \\
\hline & Jumlah & 577 & 9 & 100 & 71824 & 100 \\
\hline
\end{tabular}

Keterangan: *limbah elektronik dengan persentase berat terbesar **limbah elektronik dengan persentase volume terbesar limbah lain-lain berupa limbah kipas angin, exhaust fan, amplifier, microphone, UPS, camera video, audio visual, receiver, video processor, digital video effect, film projector, slide projector, photo tustel, GPS receiver, spektrofotometer, analytical balance electric, audio generator, server, hub

Tabel 8.

Limbah Elektronik Departemen Teknik Kelautan ITS

\begin{tabular}{|c|c|c|c|c|c|c|}
\hline $\begin{array}{l}\mathrm{N} \\
\text { o. }\end{array}$ & $\begin{array}{c}\text { Limbah } \\
\text { Elektron } \\
\text { ik }\end{array}$ & $\begin{array}{c}\text { Jumla } \\
\mathrm{h}\end{array}$ & $\begin{array}{l}\text { Berat } \\
(\mathrm{kg})\end{array}$ & $\begin{array}{c}\% \\
\text { berat }\end{array}$ & $\begin{array}{l}\text { Volume } \\
\left.\mathrm{m}^{3}\right)\end{array}$ & $\begin{array}{c}\% \\
\text { volume }\end{array}$ \\
\hline 1 & Monitor & 50 & 559.9 & 34 & 2757 & 29 \\
\hline 2 & $\begin{array}{l}\text { CPU } \\
\text { Keyboar }\end{array}$ & 44 & 220 & 13 & 2200 & 23 \\
\hline $3 c$ & & 22 & 20.95 & 1.25 & 30 & 0.3 \\
\hline 4 & Printer & 15 & 74.8 & 4 & 352 & 4 \\
\hline 5 & Scanner & 1 & 2 & 0.12 & 8 & 0.1 \\
\hline 6 & $\mathrm{AC}^{*}$ & 13 & 563.5 & 34 & 3374 & 36 \\
\hline 7 & OHP & 3 & 30 & 2 & 88 & 0.9 \\
\hline 8 & $\begin{array}{l}\text { Stavolt } \\
\text { Dispens }\end{array}$ & 16 & 100.5 & 6 & 72 & 1 \\
\hline & $r$ & 1 & 5 & 0.30 & 123 & 1.3 \\
\hline 0 & Lain- & 1 & 30 & 2 & 406 & 4 \\
\hline & in & 19 & 64.1 & 3.8 & 75.9 & 0.8 \\
\hline & Jumlah & 185 & 1670.75 & 100 & 9485 & 100 \\
\hline
\end{tabular}

Keterangan: *limbah elektronik dengan persentase berat dan volume terbesar limbah lain-lain berupa limbah power supply, UPS, ethernet, speaker, harddisk, CD room, fax modem, raket nyamuk, mouse

Dari hasil pendataan limbah elektronik tersebut, didapatkan jumlah limbah elektronik yang terdapat pada 7 departemen yang diteliti adalah 1289 unit limbah elektronik, dengan berat $16180.1 \mathrm{~kg}$ dan volume $100.5 \mathrm{~m}^{3}$.

\section{B. Kondisi Pengelolaan Limbah Elektronik}

Sebagian besar departemen yang diteliti belum sepenuhnya melaksanakan pengelolaan limbah elektronik yang sesuai dengan peraturan pengelolaan limbah B3 di Indonesia. Mekanisme pengelolaan limbah elektronik di masing-masing departemen ditunjukkan pada Gambar 1. 


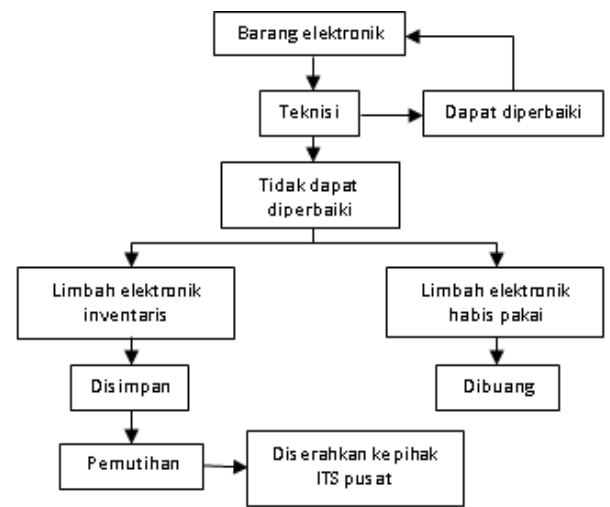

Gambar 1. Mekanisme Pengelolaan Limbah Elektronik ITS.

Limbah elektronik habis pakai seperti limbah lampu, baterai, dan perlengkapan laboratorium dari tiap departemen tidak wajib untuk disimpan, dan dapat dibuang secara langsung. Limbah elektronik habis pakai yang dibuang akan dikumpulkan di Tempat Penampungan Sementara (TPS) milik ITS. TPS yang dimiliki ITS bukan merupakan TPS B3, sehingga seharusnya limbah elektronik (sebagai limbah B3) tidak boleh masuk ke TPS tersebut. Limbah elektronik yang merupakan barang milik negara $(\mathrm{BMN})$ harus disimpan pada ruang penyimpanan limbah terlebih dahulu hingga melalui proses pemutihan/penghapusan dan dapat dipindah ke gudang milik ITS.

Aspek teknis penyimpanan limbah elektronik (sebagai limbah B3) diatur dalam beberapa peraturan yang berlaku di Indonesia, diantaranya: PP RI No. 101 Tahun 2014, Peraturan Menteri Lingkungan Hidup No. 30 Tahun 2009 serta Keputusan Badan Pengendalian Dampak Lingkungan No. 01 Tahun 1995. Dari 3 peraturan tersebut, terdapat berbagai aspek pengelolaan yang harus dilakukan. Berikut rincian penjelasannya beserta kondisi pengelolaan yang telah dilakukan pada masing-masing departemen.

1. Lokasi penyimpanan limbah elektronik

Ruang penyimpanan limbah elektronik diharuskan berada di daerah yang bebas dari banjir, jauh dari bahan berbahaya, serta memiliki keterangan nama ruangan dan simbol limbah B3 di depan ruangan [6][9]. Seluruh departemen yang diteliti sudah memiliki ruang penyimpanan yang berada di area bebas banjir serta jauh dari bahan berbahaya. Belum terdapat departemen yang membuat keterangan nama ruangan dan simbol limbah B3, sehingga tidak dapat diketahui bahwa ruangan tersebut merupakan tempat penyimpanan limbah elektronik. Pada Gambar 2 ditunjukan contoh lokasi ruang penyimpanan limbah elektronik milik departemen yang diteliti.

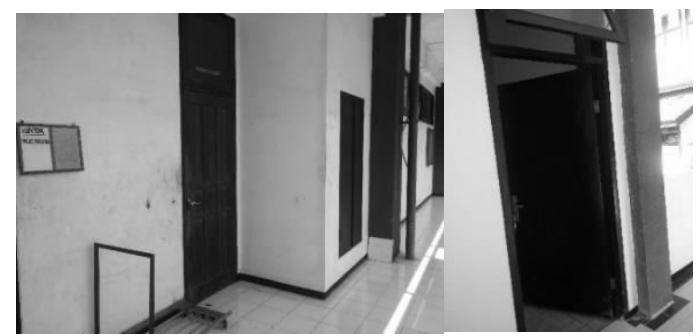

Gambar 2. Lokasi Ruang Penyimpanan Limbah Elektronik (Departemen Teknik Lingkungan dan Arsitektur).

2. Kapasitas ruang penyimpanan
Ruang penyimpanan limbah elektronik harus dirancang untuk dapat menampung limbah sesuai dengan laju timbulannya [10]. Departemen Teknik Lingkungan, Arsitektur, dan Teknik Geofisika sudah memiliki ruang penyimpanan dengan kapasitas yang memadai dan dapat menampung limbah dengan baik, yaitu tetap memberikan ruang untuk operasional dan mobilisasi di dalam ruang penyimpanan. Sementara departemen lainnya belum memiliki ruang dengan kapasitas yang cukup untuk dapat menampung limbah elektronik. Salah satu penyebab penuhnya ruang penyimpanan disebabkan karena ruang penyimpanan juga digunakan untuk menyimpan limbah non-elektronik. Sehingga kapasitas ruang menjadi kurang karena banyaknya limbah non-elektronik yang ikut disimpan. Keterbatasan ruang penyimpanan menyebabkan sebagian limbah elektronik disimpan di lokasi lain seperti ditunjukan pada Gambar 3.
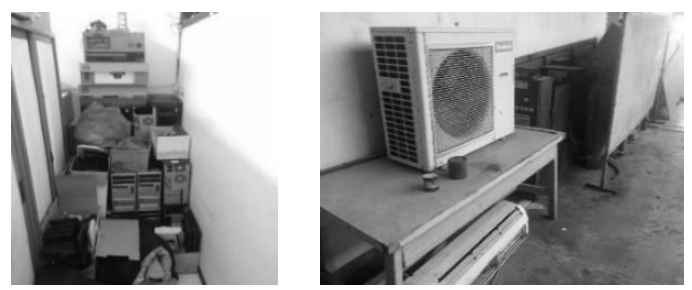

Gambar 3. Lokasi Lain Penyimpanan Limbah Elektronik.

(Departemen Sistem Informasi dan Departemen Teknik Elektro)

\section{Peletakan limbah elektronik}

Ruang penyimpanan limbah elektronik harus memiliki tata letak yang baik. Limbah dapat ditumpuk untuk dengan menggunakan rak. Kemudian jarak minimal antar blok adalah $60 \mathrm{~cm}$ [9][10]. Sebagian besar departemen yang diteliti belum membuat tata letak limbah elektronik di dalam ruang penyimpanan. Limbah yang disimpan dalam ruang penyimpanan diletakkan secara acak. Beberapa departemen sudah menggunakan rak untuk penumpukan limbah elektronik, namun sebagian departemen melakukan penumpukan tanpa menggunakan rak seperti ditunjukkan pada Gambar 4.

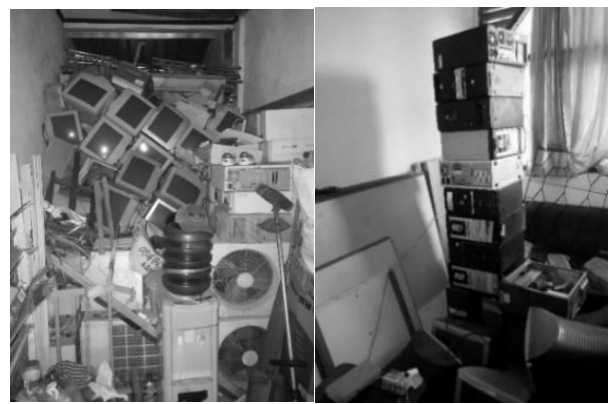

Gambar 4. Penumpukan Limbah Elektronik (Departemen Teknik Kelautan dan Departemen Teknik Lingkungan).

\section{Penerangan ruang penyimpanan}

Ruang penyimpanan limbah elektronik harus memiliki penerangan yang memadai, baik dari lampu maupun dari sinar matahari. Jarak minimal lampu dengan limbah paling dekat adalah 1 meter [6][9][10]. Departemen Teknik Lingkungan dan Departemen Teknik Elektro sudah memiliki ruang penyimpanan dengan penerangan yang baik, sedangkan beberapa departemen lainnya masih terdapat kekurangan 
seperti lampu yang rusak, belum adanya kaca jendela, dan jarak antara limbah dengan lampu yang terlalu dekat (kurang dari 1 meter).

5. Ventilasi ruang penyimpanan

Ruang penyimpanan harus memiliki ventilasi yang memadai. Luas ventilasi yang memadai untuk ruang penyimpanan adalah 5\% dari luas lantai ruangan. Kemudian ventilasi harus dilengkapi dengan kasa penutup untuk mencegah hewan masuk kedalam ruang penyimpanan [9][10][11]. Seluruh departemen sudah memiliki ventilasi pada ruang penyimpanan limbah elektronik. Ventilasi ruang penyimpanan pada Departemen Teknik Lingkungan, Teknik Geofisika, dan Teknik Elektro sudah sesuai dengan standar. Sedangkan pada departemen lainnya belum memiliki ventilasi yang cukup sehingga sirkulasi udara di dalam ruangan menjadi kurang. Seluruh departemen belum memasang kasa penutup pada ventilasi ruangan.

6. Kondisi fisik bangunan penyimpanan

Bangunan ruang penyimpanan limbah elektronik harus mampu melindungi limbah elektronik dari sinar matahari dan air hujan/kebocoran dengan adanya atap maupun dinding. Lantai ruangan harus kedap air, tidak bergelombang, kuat dan tidak retak [6][9]. Seluruh departemen yang diteliti sudah memenuhi standar bangunan ruang penyimpanan. Bangunan ruang penyimpanan yang dimiliki masing-masing departemen sudah memiliki dinding dari beton dengan ketebalan sekitar 20 $\mathrm{cm}$, atap pelindung, serta lantai yang kuat dan tidak retak. Pada Departemen Sistem Informasi terdapat kerusakan pada atap sehingga perlindungan terhadap sinar matahari dan air hujan menjadi berkurang, seperti ditunjukkan pada Gambar 5.

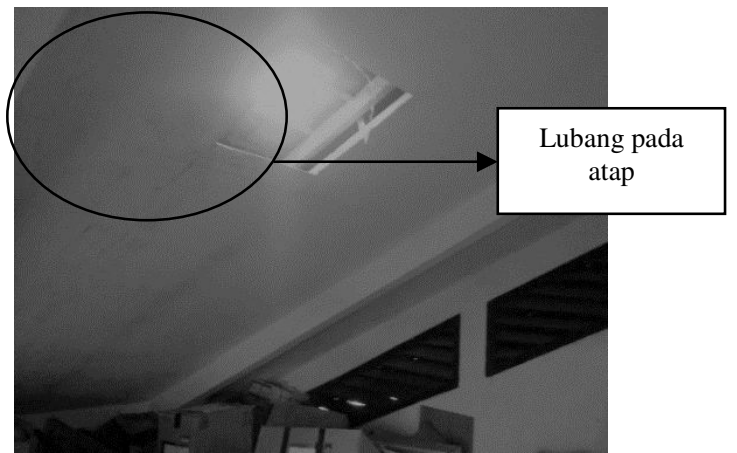

Gambar 5. Kerusakan Atap Ruang Penyimpanan Limbah Elektronik Departemen Sistem Informasi ITS

\section{Pelabelan limbah elektronik}

Limbah elektronik yang disimpan seharusnya memiliki label limbah B3 yang berisikan informasi terkait limbah tersebut. Label limbah B3 harus dilekatkan pada kemasan limbah B3 dan pada titik yang mudah untuk dilihat [6][9][10]. Dari seluruh departemen yang menjadi objek penelitian, belum terdapat departemen yang memberikan label limbah B3 pada limbah elektronik yang disimpan. Tiap departemen sudah melakukan pendataan limbah elektronik namun belum lengkap. Belum terdapat data tanggal dihasilkannya limbah serta lama waktu penyimpanan limbah tersebut di ruang penyimpanan. Data tanggal dihasilkan limbah dibutuhkan untuk menghitung laju timbulan limbah elektronik pada masing-masing departemen tiap satuan waktu.

7. Alat penanggulangan keadaan darurat
Alat penanggulangan keadaan darurat harus tersedia di ruang penyimpanan limbah elektronik. Alat yang harus disediakan minimal adalah alat pemadam api dan alat lainnya sesuai dengan kebutuhan [6]. Departemen Teknik Lingkungan dan Arsitektur telah menyediakan alat pemadam api di dekat ruang penyimpanan. Namun alat pemadam api tersebut berada di ruangan lain sehingga akses menjadi sulit karena terdapat kemungkinan ruangan tersebut dikunci ketika terjadi keadaan darurat. Selain alat pemadam api, beberapa departemen juga telah menyediakan alat penanggulangan keadaan darurat lainnya seperti evacuation alarm.

\section{Faktor yang Mempengaruhi Pengelolaan Limbah} Elektronik

Dari hasil observasi kondisi pengelolaan limbah elektronik saat ini, ditemukan beberapa kekurangan pihak departemen dalam mengelola limbah elektronik. Kekurangan disebabkan karena beberapa faktor yang mendasarinya. Berikut rincian penjelasan faktor-faktor yang mempengaruhi pengelolaan limbah elektronik di unit pendidikan ITS.

\section{Faktor ruang}

Ruang penyimpanan yang dimiliki sebagian departemen masih belum mencukupi kebutuhan penyimpanan limbah elektronik. Beberapa ruang penyimpanan seperti yang dimiliki oleh Departemen Biologi dan Departemen Teknik Kelautan tidak mampu menampung limbah elektronik. Kapasitas ruang penyimpanan tidak dapat bertambah, namun limbah elektronik terus bertambah sehingga terjadi akumulasi limbah hingga ruang penyimpanan menjadi sangat penuh. Selain itu, ruang penyimpanan digunakan untuk menyimpan jenis limbah nonelektronik, sehingga volume limbah di dalam ruang penyimpanan menjadi sangat penuh. Terbatasnya ruang penyimpanan ini secara langsung dapat menimbulkan kesulitan dalam:

a. upaya pemilahan limbah elektronik;

b. peletakan limbah elektronik;

c. pemeliharaan ruang penyimpanan (pembersihan, perbaikan, dan inspeksi limbah).

Upaya yang dapat dilakukan oleh pihak ITS ataupun departemen untuk menangani masalah ruang penyimpanan yaitu:

a. standarisasi ruang penyimpanan limbah elektronik bagi seluruh unit pendidikan,

b. pemisahan limbah elektronik dan non-elektronik agar tidak disimpan dalam ruang penyimpanan yang sama;

c. penetapan batas waktu penyimpanan limbah elektronik di ruang penyimpanan milik unit pendidikan.

2. Faktor sumber daya manusia

Sumber daya manusia pihak departemen memiliki peran penting dalam pengelolaan limbah elektronik. Sumber daya manusia merupakan elemen pendukung dalam suatu sistem pengelolaan lingkungan. Sumber daya manusia harus memiliki keahlian dan pengetahuan sesuai dengan tugas yang dikerjakan, yaitu mengelola limbah B3 khususnya limbah elektronik. Selain itu, sumber daya manusia seharusnya juga memiliki kemampuan untuk melakukan audit internal serta evaluasi secara keseluruh terhadap lingkup tugas yang dikerjakan. Pengetahuan tentang pengelolaan limbah B3 dapat dimiliki dengan melakukan pelatihan [12]. Upaya yang dapat dilakukan oleh pihak ITS ataupun departemen untuk menangani masalah sumber daya manusia yaitu memberikan 
pelatihan tentang pengelolaan limbah B3 khususnya limbah elektronik kepada tenaga kependidikan yang bertugas dalam penanganan limbah B3. Selain itu juga perlu dipertimbangkan untuk penambahan elemen baru pada struktur organisasi ITS maupun departemen, yaitu elemen pengelola limbah B3.

3. Faktor kebijakan

Pengelolaan limbah elektronik yang dilakukan pihak departemen harus didukung dengan aturan atau kebijakan yang ditetapkan oleh pimpinan ITS. Pemimpin organisasi harus membentuk, mengimplementasikan, dan menjaga kebijakan lingkungan dalam suatu sistem manajemen lingkungan [12]. Namun saat ini belum terdapat kebijakan khusus yang dibuat oleh ITS tentang pengelolaan limbah elektronik, yang mempengaruhi sistem pengelolaan pada tiap elemen di ITS khususnya unit pendidikan. Pihak departemen tidak memiliki acuan dalam mengelola limbah elektronik yang dihasilkan sehingga terjadi ketimpangan dalam kondisi eksisting pengelolaan limbah elektronik di tiap departemen. Ranah dan lingkup pengelolaan limbah elektronik antara ITS dengan unit pendidikan belum diatur sehingga masih belum jelas mekanisme pengelolaan yang harus dilakukan oleh unit pendidikan. Upaya yang dapat dilakukan pihak ITS untuk menangani masalah kebijakan yaitu:

a. menyusun kebijakan dan SOP pengelolaan limbah elektronik dalam lingkup ITS secara tertulis;

b. melakukan sosialisasi dan koordinasi dengan unit pendidikan untuk menangani permasalahan yang dihadapi pihak departemen dalam mengelola limbah elektronik, seperti tidak tersedianya ruang penyimpanan khusus limbah elektronik atau tidak adanya sumber daya manusia yang kompeten dalam mengelola limbah elektronik.

4. Faktor mekanisme pemutihan barang milik negara

Barang elektronik milik negara yang telah menjadi limbah tidak diperbolehkan untuk dibuang ataupun diperjualbelikan. Limbah elektronik tersebut harus disimpan hingga dilakukannya pemutihan oleh pihak ITS. Barang elektronik tersebut tidak diperbolehkan untuk dibuang karena merupakan aset milik negara, sehingga ketika sudah tidak digunakan maka harus dikembalikan kepada negara. Mekanisme pemutihan barang milik negara di ITS belum berjalan dengan optimal. Ketidakjelasan pelaksanaan proses pemutihan barang milik negara mempengaruhi jangka waktu penyimpanan limbah elektronik di ruang penyimpanan limbah elektronik pada masing-masing departemen. Limbah elektronik dapat disimpan hingga puluhan tahun apabila proses pemutihan tidak dilakukan. Sedangkan menurut peraturan, penyimpanan limbah B3 paling lama adalah 365 hari (1 tahun). Beberapa kasus yang terjadi akibat ketidakjelasan pelaksanaan proses pemutihan diantaranya:

a. proses pengajuan pemutihan telah dilakukan oleh pihak departemen, namun pemutihan belum dapat dilakukan karena gudang penyimpanan milik ITS sudah penuh sehingga belum dapat menampung tambahan limbah dari departemen;

b. penghapusan barang milik negara telah dilakukan, namun barang tersebut belum dapat dipindahkan dari gudang departemen hingga waktu yang saat ini;

c. proses penghapusan tidak dilakukan tiap tahun; d. proses penghapusan membutuhkan waktu yang lama (pengajuan penghapusan kepada Kementerian Keuangan RI adalah 3-4 bulan, revisi dokumen apabila proses penghapusan gagal adalah 6 bulan sejak pengajuan awal dilakukan).

Upaya yang dapat dilakukan oleh pihak ITS dalam menangani permasalahan pemutihan barang milik negara yaitu dengan menetapkan sistem pemutihan barang milik negara secara tertulis dan menyusun jadwal rutin pemutihan sesuai dengan kebijakan yang berlaku.

\section{KESIMPULAN}

Berdasarkan penelitian yang telah dilakukan, maka dapat diambil kesimpulan sebagai berikut:

1. Unit pendidikan ITS yang diteliti saat ini menyimpan berbagai jenis limbah elektronik, yaitu perangkat IT seperti: CPU; keyboard; mouse, laptop, printer; faksimile; dan mesin fotokopi, kemudian alat elektronik rumah tangga berukuran besar seperti: lemari pendingin; kipas angin dan $\mathrm{AC}$, alat elektronik untuk pencahayaan serta alat elektronik untuk laboratorium.

2. Unit pendidikan ITS yang diteliti saat ini menyimpan limbah elektronik sejumlah 1289 unit, dengan total berat $16180,1 \mathrm{~kg}$ dan total volume $100,5 \mathrm{~m}^{3}$.

3. Sistem penyimpanan limbah elektronik di Unit Pendidikan ITS yang diteliti saat ini masih belum sesuai dengan peraturan tentang aspek teknis pengelolaan limbah B3.

4. Faktor-faktor yang mempengaruhi pengelolaan limbah elektronik di unit Pendidikan ITS yang diteliti diantaranya:

a. keterbatasan kapasitas ruang penyimpanan limbah elektronik;

b. kurangnya pengetahuan SDM pada masing-masing departemen tentang pengelolaan limbah B3 khususnya limbah elektronik;

c. belum adanya kebijakan dari pimpinan ITS tentang pengelolaan limbah elektronik; dan

d. belum jelasnya mekanisme pemutihan barang milik negara.

\section{DAFTAR PUSTAKA}

[1] P. Kiddee, R. Naidu, and M. H. Wong, "Electronic Waste Management Approaches : An Overview," Waste Manag., vol. 33, pp. 1237-1250, 2013.

[2] D. McCann and A. Wittmann, "E-waste Prevention, Take-back System Design and Policy Approaches," 2015.

[3] Official Journal of the European Union, "Directive 2012/19/EU Of The European Parliament And Of The Council of 4 July 2012 on Waste Electrical and Electronic Equipment (WEEE)," 2012.

[4] S. Wahyono, "Kebijakan Pengelolaan Limbah Elektronik Dalam Lingkup Global dan Lokal,” Banten, 2012.

[5] W. Astuti, Purwanto, and E. Damanhuri, "Studi Persepsi dan Perilaku Jasa Servis Dalam Memperpanjang Aliran Limbah Elektronik (E-Waste) di Kota Semarang," in Prosiding Seminar Nasional Pengelolaan Sumberdaya Alam dan Lingkungan, 2012.

[6] Pemerintahan Republik Indonesia, "Peraturan Pemerintah Republik Indonesia Nomor 101 Tahun 2014 Tentang Pengelolaan Limbah Bahan Berbahaya dan Beracun," Jakarta, 2014.

[7] Massachusetts Institue of Technology, "Universal and Electronic Waste Management for the MIT Community," Amerika.

[8] Jomo Kenyatta University of Agriculture and Technology, "EWaste Management Policy," Kenya.

[9] Menteri Negara Lingkungan Hidup Republik Indonesia, "Peraturan 
Menteri Negara Lingkungan Hidup Nomor 18 Tahun 2009 Tentang Tata Cara Perizinan Pengelolaan Limbah Bahan Berbahaya dan Beracun," Jakarta, 2009

[10] Badan Pengendalian Dampak Lingkungan, "Keputusan Kepala Badan Pengendalian Dampak Lingkungan Nomor 01 Tahun 1995 Tentang Tata Cara dan Persyaratan Teknis Penyimpanan dan Pengumpulan Limbah Bahan Berbahaya dan Beracun,” 1995.
[11] BADAN STANDART NASIONAL, SNI 03-6572-2001 tentang Tata Cara Perancangan Sistem Ventilasi dan Pengkondisian Udara Pada Bangunan Gedung. Jakarta: Badan Standardisasi Nasional, 2001.

[12] International Organization of Standardiztion, "ISO/FDIS 14001:2015 International Standard: Environmental Management Systems - Requirements with Guidance for Use," 2015. 